\title{
PAST AS FUTURE: THE SOUTH AFRICAN WAR, DUTCH OBSERVERS AND MILITARY MEMORY ${ }^{\mathrm{a}}$
}

\author{
Henk de Jong ${ }^{\mathrm{b}}$ \\ Netherlands Defence Academy
}

"Het is ons niet minder om Nederland zelf te doen dan om Zuid-Afrika."

\begin{abstract}
In 1900, the Dutch Ministry of War sent four military observers to South Africa, in an attempt to come to terms with the latest developments in the military field. Once in South Africa, the promising young Dutch officers selected for the mission remained focused strongly on decisive battles Jominian style, which they considered relevant for future warfare in Europe. They almost completely ignored guerrilla warfighting. However, inspired by the Boer commandos, their analysis of the Anglo-Boer War also ended in pleas for a fundamentally new relationship between army and society in Holland, and a new Dutch militia army organisation (a volksleger), comparable to the Boers' commandos. Fascinatingly, this ideal of a militia army had probably much more to do with the observers' interpretation of the

Scientia Militaria, South African Journal of Military Studies, Vol 41, Nr 1, 2013, pp. 34-64

doi: $10.5787 / 41-1-1052$

Dutch national past and the values they regarded characteristic of it, than with contemporary South Africa, since the earliest forms of the Dutch army were also believed to have been a volksleger. In this way, the
\end{abstract}

${ }^{a}$ This article elaborates on research papers presented at the 2010 conference of the Historical Association of South Africa in Potchefstroom (Milestones: Commemorating Southern African history/Mylpale: Herdenking van SuiderAfrikaanse geskiedenis) and the 2011 conference of the Southern African Historical Society at the University of KwaZulu-Natal in Durban (The past and its possibilities: Perspectives on Southern Africa). Comments and suggestions are very much welcomed at h.d.jong.02@nlda.nl

${ }^{\mathrm{b}}$ Henk de Jong is assistant professor in military history at the Faculty of Military Sciences of the Netherlands Defence Academy/Royal Military Academy in Breda, the Netherlands. His fields of interest and research are colonial warfare and wars of decolonisation. 
military observers from the Netherlands converted the South African present into Dutch history to serve their country's national future.

\section{Introduction}

Teaching history at a military academy, one is regularly confronted with the fascinating but also puzzling ways in which military professionals tend to go about with the past, present and future. ${ }^{2}$ Obviously, military professionals consider themselves to be oriented in the first place towards the forthcoming developments in the field of security issues, and understandingly so. Undoubtedly, however, they are equally rooted in contemporary issues and topical viewpoints, for good reasons as well. At the same time, military professionals have a strong inclination to respect the past. They like to study (military) history in order to gather lessons learned from it and timeless military fundamentals, which they declare subsequently applicable to both present and future alike. This amounts to a rather complex whole, in which the differences between past, present and future can become blurred or may even be distorted.

It seems to be no new phenomenon. A Dutch case from around 1900 might be illuminating in this respect. It is of particular interest to a South African public, given the fact that it features the Dutch (military) confrontation with the South African War (1899-1902).

To anticipate the conclusions of this article: around 1900, aspects of contemporary South Africa seemed to have been identified as elements of a Dutch past, by the Dutch in general as well as by the Dutch military observers who were posted in the country. These aspects of contemporary South Africa were seen as the remnants of a national past lost in time and place, and functioning within the context of the hope of a stronger national Dutch future. To be more precise, the South African present was converted into Dutch history, to serve that country's national future. Interestingly, this instrumentalisation of the South African present cannot be characterised only as stemming from pure nostalgia alone, or as an invention of tradition that completely lacked sophistication and critical touch, as one might perhaps expect. The Dutch military professionals, especially, turned out to be very critical of the past and the present, and of South Africa and Holland, despite their anachronistic presentism. The professionals were driven by radical liberal political ideals, and they challenged the cliché that soldiers are always predisposed to a conservative and reactionary relation to past and tradition. ${ }^{3}$ 


\section{South Africa and the Netherlands: Shared Values?}

Roughly, the Dutch relationship with South Africa after 1850 can be subdivided into three distinct phases. Before 1881: a phase of little interest and implicit criticism on the supposed traditionalism and backwardness of South Africa. Around 1900: a phase of immense sympathy for the Boers, not to say hysterical glorification of them, with almost constant references to the Dutch volksplanting at the Cape of Good Hope in 1652. Between 1960 and 1994: a phase of fierce reaction against apartheid.

To start with the last phase, the contrast between the Netherlands and South Africa had evidently widened immensely by 1960 . South Africa had evolved into emphasising segregation on the basis of race or class, and on emphasising the notion of different places and paces for different groups, resulting also in the repression of most of its opposition. In the same years, the Netherlands came to be characterised by radical pleas for equality and freedom. Democratisation on all levels of society suddenly typified the country, including anti-authoritarian preferences, appeals to universalism and human rights, and sympathy for liberation movements, whatever their ideas. ${ }^{4}$

This had a lot to do with what had happened in the Netherlands during the Second World War and immediately after. Initially, the country was very busy recovering from the war, economically and mentally, and not at all inclined to politics based on moral indignation. Furthermore, during this timeframe, the country was confronted with the struggle for national liberation in Indonesia. It found itself fighting as a colonial power for white domination over a non-white majority. This meant that, in general, the Dutch could understand the ideas of Verwoerd and Vorster, emphasising "controlled development". The notion of Baasskap (Bossiness) was not strange to them, nor the philosophy of separate development timetables for segregated self-governing groups. Understandably so, the Nederlandse stam (Dutch roots) in the Cape remained as popular as before. Shared language, religion, ideas, and shared destinies (anti-communism) were emphasised. After 1945, Dutch citizens chose to immigrate to the Cape.

Around 1960, however, things started to change rapidly. The coming of age of the baby-boomer generation coincided with a complete transformation of ideas about the Second World War, Indonesia, and about society in general. The trauma of the German occupation resulted in an extreme sensitivity to anything that only hinted at identity cards, segregation and forced removals, and stimulated a strong aversion against authoritarian regimes and racial thinking. The loss of Indonesia strongly reinforced this sensitivity, which was accompanied by feelings of shame 
and guilt. Were the Dutch in Indonesia not guilty of (social and racial) separation, inequality, exploitation and disregard for self-determination and national rights, and even military excesses? In reaction to all this, the younger generation now strongly emphasised freedom and equality. All this changed of course the perception of South Africa fundamentally. ${ }^{5}$

Secularisation and the ontzuiling (de-pillarisation) of Dutch society did the rest. Especially within the Protestant communities, South Africa had been popular. In these circles, the paternalistic notion of a white roeping (calling), the ideal to bring Western civilisation to the black communities and thereby educate them, as well as the acceptance of different tempos/directions of development, had all been strongly applauded. It was also here that the idea of stamverwantschap (kinship) had been cultivated (the idea of religious and language kinship, and the notion of an interrelated Dutch and South African history). With the secularisation of the Dutch society, from the sixties onwards, these old meta-narratives, as well as the groups that supported them, started to lose their aura of being self-evident.

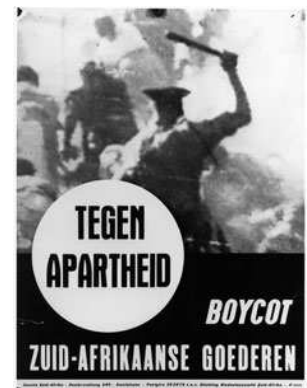

Illustration 1: Protest against apartheid in the Netherlands after 1960.

Paradoxically, however, the morally tainted worldview after 1960, now very critical of South Africa, concealed an idealism that evidently was the residue of precisely this older protestant positive stance on South Africa. ${ }^{6}$ Around 1900, the enthusiasm for South Africa, not to say the identification with it, had also been tainted by a worldview emphasising freedom and equality, but now positively applied instead of negatively. Anyone visiting the Netherlands today can still observe it. Visitors will be startled by the way South Africa (and the South African War) must have mingled in this sense with everyday life in Holland around 1900. Countless streets, monuments, and even complete Transvaalwijken (Transvaal districts) referred to the Boers, and especially to their moral values. Indeed, much more than admiring the heroic per se, or remembering the historical importance of 
the Boers, the Dutch ultimately seemed to have admired the South African ethics, as much as they later came to criticise them. This has been confirmed by many researchers, like Schutte, Bossenbroek, De Graaf, and very recently also Kuitenbrouwer. ${ }^{7}$ They all agree that around 1900 the intensity of the pro-Boer and anti-British movement in the Netherlands centred on the moral standards supposedly embodied by the Boers.

Until the Jameson Raid, the Dutch considered the Boers to be lazy, inflexible, narrow-minded, primitive, reactionary, intolerant, bigoted and bearded, something Dutch liberal citizens certainly did not want to be themselves. Around 1900, however, the Boers were celebrated as a pious and freedom-loving people, surrounded by hypocritical Englishmen, black devils, and a godforsaken natural environment. Especially during the years of the Boer War, no limits were set on this positive value-oriented image. Numerous pro-Boer movements were now formed, many petitions signed, sympathy statements written, money raised for ambulances, and the right of the Boers to freedom and independence was asserted everywhere. The Boers were described as a simple and honest people who had put their trust in God, a chosen people living in a desolate wilderness sent to build civilisation out of nothing, and fighting bravely against natives and the English armies alike. "They were the pioneers of Christianity and civilisation," as the then very famous but now rightly forgotten Dutch author Louwrens Penning (1854-1927) claimed. ${ }^{8}$ His novels (typically all written before he managed to visit South Africa) featured Boers bravely fighting for freedom and justice, "with a psalm on their lips and armed with gun and Bible". 9 After 1880, and even more so after 1899, this image became almost undisputed in the Netherlands. ${ }^{10}$

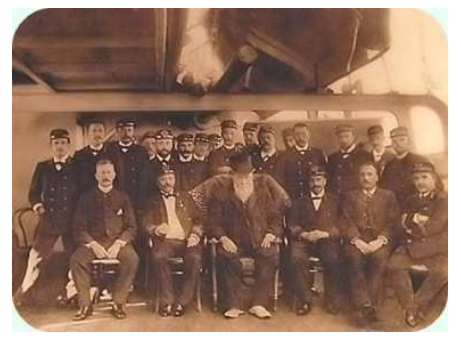

Illustration 2. President Kruger "rescued" by the Dutch, on the cruiser HNLMS Gelderland.

In summary, the conflict between Boer and Brit was considered by the Dutch to be far more than a skirmish on the frontier of a colonial empire. The British 
Rooineks (soldiers) stood for immoral modern values in international politics, for disgustingly raw power politics. The Boers, on the other hand, represented highspirited ideals that once had made Holland mighty.

That was the crucial implication. The Boers were freedom-loving individuals, fighting courageously for independence and freedom at the Cape against superior forces, just like the Dutch themselves had done against Spain! Many in Holland became convinced that the Boers, essentially a small Dutch Calvinistic nation, had kept alive fundamental values of the Gouden Eeuw (Golden Age), thousands of miles away from Holland, whereas the modern Dutch themselves were slackened by their wealth, materialism and a lack of real faith. The Afrikaander was made into an heir of the "true" Dutch culture, religion and history, whether he liked it or not (most of them evidently did not). Was it not "old" Holland that stood up against the Rooineks? Of course it was. At Majuba, Laingsnek and Spion Kop, the true spirit of Holland reigned, the spirit of the seventeenth century! The Boers were worthy of the glorious Dutch past, no longer strange beard-wearing living fossils. They were the "Geuzen" of the South African veld. These freedom-loving kinsmen could serve as a model of inspiration for the regeneration of the Dutch, as inspiring "living history". The Netherlands had become weak, opulent and decadent. Luckily, around the Cape, a group of idealistic, pious and courageous expatriates had miraculously kept alive the values that had been lost in the Netherlands. Indeed, contemporary South Africa was converted into Dutch history, to serve this country's national future.

\section{The Boer Soldiers: Incarnations of "the Best from Dutch History"?}

Fascinatingly, the Dutch found these "historical" national values, which hinted at a possible new glorious Dutch future, best embodied in the Boer soldiers. This is remarkable, given the fact that around 1900, the Netherlands also cherished a tradition of anti-militarism, and even pacifism (today there is still a certain aversion to military monuments, military parades and the display of uniforms in public). Holland liked to present itself as a country with a very long practice of (armed) neutrality, and with a preference for resolving armed conflicts through international law and negotiations, instead of coercion by military might. However, around 1900 , the enthusiasm for Boer military swept the country to the point of hysteria. It became as immense as it was intense. ${ }^{11}$

This is understandable only when one realises, as already suggested above, that this hysteria was related to the mounting frustration over the national weakness of the Dutch, and the subsequent attempts to regain strength and renew national self- 
esteem. The fierce fighting in the colonies, in Aceh, Lombok and later Bali, can also be interpreted in this way. These were all efforts to regain former might and glory. The hysteria regarding South Africa in general, and the Boer military in particular, must be seen in this context.

The Boer soldiers represented everything the Dutch wanted to be, but were not for the moment. They embodied piety and soberness and love for independence, but also strength, drive, vitality and the will to rise up against England. ${ }^{12}$ The generals above all, like Botha, Cronjé, De la Rey, De Wet, and to a lesser degree Smuts, stood for vigour as well as the moral high ground. The combination was irresistible. The Boers were admired not as brilliant soldiers, but much rather as models of pure and unyielding force. They seemed driven by sheer love of freedom, rather than by lust for land, gold and diamonds, as the British were. They stood up for the ideals of freedom, self-determination, faith and related values, unyieldingly and courageously.

Of all the Boer soldiers, Christiaan Rudolph de Wet (1854-1922), the Bittereinder (die-hard), the hero of the guerrilla phase of the Second Boer War, seems to have been most popular in the Netherlands for this reason, after Kruger of course. Of street names, monuments and statues referring to Boer generals, most refer to De Wet. ${ }^{13}$ The most extraordinary and at the same time most characteristic of all these monuments is the one at the National Park De Hoge Veluwe in Otterloo. It is a column of 16 meters high, with the statue of the general at the top, standing on a solid base, with his name inscribed in relief on the column. ${ }^{14}$ Packed with symbolic imagery, it was erected in 1921 on the Otterloose Zand, shortly before the death of De Wet.

The entire monument seems to have been conceived as a monument to all Boers, with De Wet as personification and culmination of them - by literally placing him at the top - and metaphorically depicting him as the embodiment of the resistance of a small courageous nation against the opportunistic, power-hungry British Empire. De Wet's appearance and gestures endorse this view: he is represented as a symbol rather than as an individual. We find no martial poses or weapons; we are confronted with a determined, rebellious civilian who knew moral right and God were on his side. He is standing up - proud, virtuous, fist clenched, hand on his heart - against forces greater than he himself, like David versus Goliath. On the base of the column, the stylised symbolism is continued. Heads of Boers in a defensive position can be seen, almost as in a laager, or at a kopje (small hill). Although individual faces are recognisable, like those of Paul Kruger and Martinus Steyn, they, again, seem to be "types". 


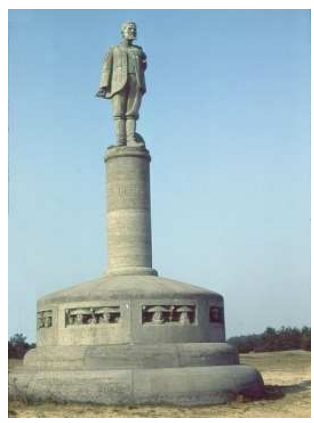

Illustration 3. Monument for Christiaan de Wet, De Hoge Veluwe, Otterloo, the Netherlands.

Apparently, the Dutch needed such images of moral force much more than they needed objective historical reality, or a narrative of the real war. In this sense, the military leaders of the Afrikaners in the Boer War were objects of admiration and commemoration. Holland remembered the moral and spiritual virtues behind the concrete persons, events and battles, such as balance, resolution, courage, force and even attachment to peace. Obviously, the famous Dutch sculptor Joseph Mendez da Costa (1863-1939) designed the monument of De Wet with this in mind, as a set of "Dutch" values carved in stone.

In summary, the remembrance of the Boer War became a value-oriented commemoration. Not real experiences, chronology, the causes and consequences of the war, the actual deeds and successful battles of the military heroes dominated it, but the supposedly moral heritage they embodied (referring often also to Van Riebeeck and the Voortrekkers). It was not the real story of the Boer War, which of course ultimately was a story of defeat that was visualised and venerated in the countless streets named after Botha, Cronjé, Joubert, squares named after Kruger, and monuments for De Wet. The abstract notion of Boer culture was honoured, with the military as its best representative. ${ }^{15}$

\section{Professional Military and South Africa}

Interestingly, it seems the experts, the Dutch military professionals, initially reacted differently towards these South African military milestones and key figures. They appear to have broken out of this simple scheme of admiration and identification. They refused to endorse the almost unquestioned euphoria in Holland about the one-dimensional relationship between Boer soldiering and Dutch values. 
Without any doubt Dutch officers could not resist romanticising and stereotyping either. Dutch officers were known to have been active in the South Africa Committees. ${ }^{16}$ In 1899, the flag of the South African Republic was hoisted in the corridors of the Royal Military Academy. Money was raised. Dreams of becoming a volunteer were dreamt. But that was it. Very few Dutch volunteers actually fought with the Boers in the Hollander Corps at Elandslaagte, or anywhere else. ${ }^{17}$ Of course, one could argue that the distance between the countries was too great, or that Holland was a neutral state, so that soldiers were formally forbidden to intervene actively. All true, but there is more to it.

Most soldiers, at least according to my analysis of the Dutch military publications on South Africa around 1900 (see the endnotes for relevant titles), did not primarily associate the Second Boer War with Dutch values and the heroic Dutch past. They concentrated far more, and critically, on the latest relevant military developments. They were interested in the fighting around Ladysmith, Kimberley and Mafeking, particularly from the perspective of possible implications for future warfare in the Netherlands.

That was also exactly why the Ministerie van Oorlog (Ministry of War) strongly felt the need to send military observers to South Africa: to come to terms with the latest developments in the military field. What were these? One simply had no clue. ${ }^{18}$ The military debate in the Netherlands centred on the Vestingwet (Blockhouse Law), the role of the field army and the Waterlinie (Water Line) in the defence of the Netherlands, the Aceh War, and conscription. ${ }^{19}$ Now suddenly this Boer War came up, on an exotic frontier, between a colonial power and a peasant militia. Everything seemed to be out of the ordinary in South Africa and interlacing: maritime blockades, sieges, pitched battles in the spirit of Jomini, ambushes and even guerrilla attacks. How to interpret this? More importantly, what could the Dutch learn from it?

To determine this, the Netherlands sent four military observers to South Africa to study the conflict between Boer and Brit, and to report on it. ${ }^{20}$ The army sent Captain JH Ram and Lieutenant LWJK Thomson (who was, in retrospect, by far the most interesting of the four). The Minister of Colonial Affairs sent two officers of the Oostindische Leger (East Indian Army): Lieutenants CJ Asselbergs and MJ Nix. They were all young, talented students of the Hogere Krijgsschool (War College), and all four had ample experience of colonial warfare in the Dutch East Indies. Asselbergs, Ram and Thomson had been decorated in Aceh. ${ }^{21}$ Nix had participated in fighting at Lombok. The republics of Transvaal and the Oranje Vrij 
Staat (Orange Free State) were prepared to receive them, with full diplomatic status. The British refused them.

\section{The Dutch Military Observer mission of 1900}

To understand what the Dutch military observers actually saw, experienced and ultimately concluded, one has to bear in mind that the Dutch arrived in South Africa around January 1900 during the stalemate after the Boers had launched their pre-emptive strikes from the Transvaal and Orange Free State into British territory. Ladysmith, Mafeking and Kimberley were besieged. However, the Boers failed to take the cities, or refused to do so. In addition, for the moment, the British colonial troops could not break the siege and relieve their garrisons. They were unable to overcome the obstacles the Boers had erected on the roads to the cities. This resulted in the strange situation that in this most modern of wars in terms of firearms and mobility everything revolved around the most static and outdated form of warfare imaginable: the siege. ${ }^{22}$

The Dutch observers joined the Boers near Colenso. Thereafter, the Dutch observers were constantly at the front, observing British attacks and charges from a close distance. They immediately noticed that the British, confronted with the Boer commandos, initially piled failure upon failure. The British commander, General Redvers Buller, who had a lot of experience in Africa, seemed to try to break through the Boer lines in the conventional "colonial style" manner. After preparatory artillery fire, the British army attacked the Boers head-on, over open terrain, in massed closed formations, releasing volley fire and sometimes even assaulting with bayonets fixed. This proved to be ineffective against the virtually invisible Boers, to say the least. The Boers specialised in cover and mobility. They waited for their enemies in thin open lines to bring them to a standstill from a distance with their modern breech-loading rifled Mausers and their indirect firing of modern artillery, or from up close with ambushes, only to disappear thereafter. The Dutch observers criticised the British for this way of assault.

At the same time, the observers were very critical of the Boers too. Actual military training seemed to have been virtually non-existent, apart from a single wapenschouw (weapons display). The Dutch military observers especially disliked the poor quality of the Boer commanders, their unrealistic and vague strategic plans, the lack of discipline and the low morale of the troops. 


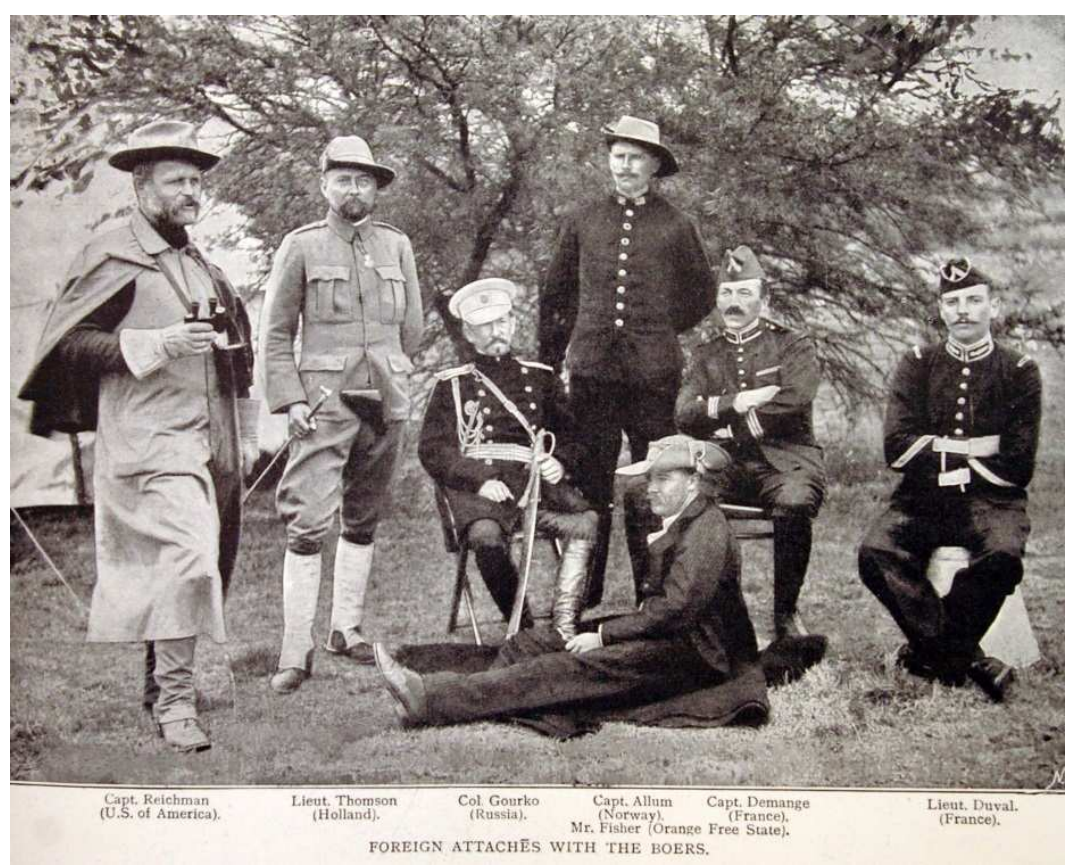

Illustration 4. "Foreign attachés with the Boers". Dutch Lieutenant LWJK Thomson second from left.

Nonetheless, at individual level, the Boers made excellent hunters, marksmen, trackers and riders. They also combined combat readiness, resilience, mobility, situational awareness and great skill with modern weaponry. The fact that a militia of armed burghers, mostly bringing their own weapons, ammunition and horses, and provisions for eight days, fought the mighty British to a standstill stunned the Dutch contingent. In amazement they observed how groups of burghers were combined into effective units of 300 to 3000 men, mostly organised by district, and choosing their own officers.

It turned out not to be enough, though. After the Black Week (10-17 December 1899), in which virtually every British offensive action failed, Buller was replaced by Field Marshal Lord Frederick Sleigh Roberts. Influenced by his experiences in India and by new German infantry doctrines, Roberts implemented different strategic and tactical principles, and succeeded. Roberts disliked the emphasis on large-scale frontal infantry offensives. He favoured avoidance of all too obvious march routes, choosing instead emphasis on mounted troops that could turn 
up at unexpected places, and preferred open lines and swift (flank) attacks on the soft spots of the enemy, rather than attacks on their centres of gravity. He also believed in concentration of firepower to obtain breakthroughs instead of volleyfiring closed lines. From January 1900 on, he received reinforcements to implement this. The war fundamentally changed character afterwards. The British broke the lines of the Boers at Colenso (ironically commanded by Buller), giving the observers much food for thought.

The Dutch were at Colenso. Or, actually, they were away for a short while. They left Colenso shortly before the flank attack that would become fatal to the Boers, paving the way for the British to Ladysmith. The Dutch did not see this coming and only afterwards learned of the successful attack. And it continued like that. Subsequently, the Dutch spoke to Koos de la Rey who wanted to march on Paardeberg to relieve Cronjé, and they decided to join him. But Cronjé surrendered that very day, 27 February 1900. Thus the Dutch also missed the biggest defeat of the Boers so far.

One is reminded of Tolstoy's War and Peace in which eyewitnesses of military clashes invariably are tricked by what is happening around them, and only at a distance in space and time appear capable of any comprehension. This was also the case with the Dutch observers. During the mission, friction reigned. Thomson, for example, started his journey with a serious faux pas. Self-indulgent as he was, he openly criticised the strategy of the Boers. According to him, they should have exploited their initial successes much better. As a result of his criticism, he was asked to leave the country. It took a lot of arguing and an appeal to his diplomatic status for him to be allowed to remain in the war zone. Not much later, Thomson was captured by the British. He was allowed to return to the Boer forces, but through Portuguese territory only. This turned out to be very time consuming.

From a medical point of view, the trip of the Dutch observers was a disaster too. Ram arrived ill and remained ill for a long time. At Vaalkranz, Thomson was wounded by shrapnel, while at Sannah's Post, a round of grapeshot exploded above Nix's head. Asselbergs tried to help Nix by arranging a British ambulance. Instead, Asselbergs was made prisoner of war. In the meantime, Nix died of his wounds and was buried with military honours in Bloemfontein on 12 April 1900. During his captivity, Asselbergs contracted typhoid, and nearly died in a hospital in Durban. Ram finally recovered, but was hit by shrapnel in July. He became ill again soon afterwards. 


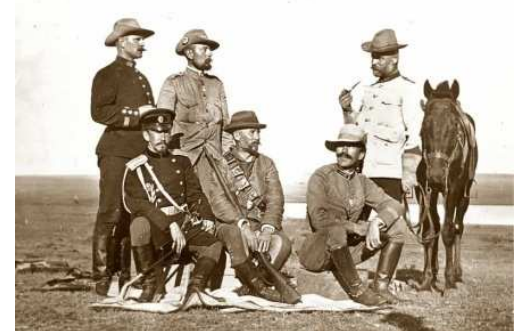

Illustration 5. International military observers during the Boer War. LWJK Thomson third from left (standing).

Despite all this, the Dutch military observers remained in a position to observe the Boer army meticulously. Under British infantry and artillery fire frequently, they visited many of the defensive lines of the Boers, joined them on their nightly reconnaissance, were present at Vaalkranz and around Ladysmith, witnessed several attacks and ambushes by Botha and De Wet, and met almost the entire political-military leadership of the Boers, among whom were key figures such as Theron, Botha, De Wet, Joubert, Cronjé, Meyer and De la Rey. In other words, the Dutch observers ultimately became very well informed about the operational and strategic considerations and decisions of the Boers, as well as the actual warfighting at tactical level.

It paid off. Once home again (they departed in the fall of 1900, when the war seemed over), ${ }^{23}$ they tried to come to grips with what they had seen. They produced an impressive amount of notes (thousands of pages, containing also the confidential cables sent by the political and military leaders of the Boers). Their ultimate report grew to a staggering nine volumes. ${ }^{24}$ It took them four years to complete, and makes for fascinating reading.

\section{Turning a Blind Eye on Guerrilla: The Dutch Military Report on South Africa}

Interestingly, what we nowadays find intriguing about the Boer War, does not seem to have interested the Dutch military observers at all. Despite their background in colonial warfare, they almost completely ignored the ultimate consequence of military actions of a small militia against a large professional army: guerrilla warfare. Notwithstanding the fact that they had served at Aceh and Lombok, and probably had been confronted with guerrillas there on an almost daily basis, the Dutch observers paid little attention to irregular warfare and counterinsurgency. 
This may come as a surprise, since nowadays the Boer War, together with the conflicts in Malaysia, Algeria and Vietnam, is considered the classic example of this kind of warfare. One could argue that the reason for this is very simple: the Dutch had left South Africa before the guerrilla phase of the war really took off. But there is again more to it. The Dutch military observers witnessed a substantial number of guerrilla activities. They had several meetings with Christiaan de Wet who spoke frankly with them about his guerrilla strategy. They were present at one of the most important war councils, in Kroonstad on 17 March 1900, at which President Steyn and Generals De Wet and De la Rey explicitly declared that from then on, the Boers would operate in small mobile commandos avoiding large-scale confrontations with the British. Instead, they would focus on surprise actions in the rear of the British army, with the aim of cutting their lines of communication and supply, seizing their resources, laying ambushes, and capturing their soldiers. Finally, Asselbergs and Nix were present at a successful guerrilla attack by De Wet at Sannah's Post.

The Dutch observers, regardless of their colonial experience, however, seemed to have disliked this. Asselbergs' reaction to the combination of improvised ambush and surprise attack at Sannah's Post was typical. He did not appreciate the attack for what is was, guerrilla. According to him, De Wet should have hit much harder, especially on the fleeing British. In a similar manner, Joubert's initial strategy at Ladysmith - which also had not been aimed at the complete destruction of the English garrison - was criticised by the military observers. Colenso riddled the Dutch attachés for the same reason. Again, the Boers avoided decisive battle and operational advantages were not properly exploited. Very much the same can be said about the military confrontations at Modder River and Magersfontein.

In other words, the Dutch remained strongly focused on destroying enemy armies, in Jominian-style decisive battles. Their turning a blind eye on the guerrilla aspects of the war seems to have been determined especially by the compelling power of their Dutch/European military frame of mind. Essentially, they wanted to take home from South Africa lessons that they deemed relevant for the Dutch armed forces and future European warfare. This strongly tainted their observations in South Africa and their opinions of the war. For Europe, irregular and asymmetrical warfare simply did not seem to be a relevant new form of warfare. It was something to be used against the natives, in the lands of the natives.

However, according to Thomson, Ram and Asselbergs, the way the Boers had fought their war was relevant to future European warfare. This had to do with the new "open battlefield" observed in South Africa and the "democratic forms of 
discipline" that apparently fitted it best. Because of the introduction of breechloading automatic rifles, machine guns and quick-firing artillery, the battlefield had become more dangerous. In future warfare, closed orders (carefully monitored marching lines of volley-firing advancing infantry) would lose all relevance. As a result, in their report, the Dutch observers elaborated extensively on the future role of the Mausers, entrenched units, well-camouflaged indirectly firing artillery, as well as on attacking the enemy at great distance. They suggested that in future warfare, also in Europe, the role of firepower would become much more important, dug-in defences stronger, and cover and mobility therefore more essential.

There was a catch in this reasoning, and a very important one. Their prevailingly tactical technical analysis also implied a fundamentally new army organisation, a novel relationship between army and society, and a modern kind of training and discipline, given this military revolution. In this respect, the report contained a carefully hidden bombshell. It could be read, and ultimately was read, as a plea for nothing less than a new kind of soldier and new military values. The report argued for a well-trained, disciplined, self-thinking soldier who was able to fight without officers around. The "old" soldier could have been ill disciplined, or even drunk. All he had to do, was to stay in line. If necessary, he was simply beaten into line. Discipline was forced on him. This would no longer do in a modern war. With its open and dynamic battlefield, soldiers and officers needed to be self-acting, full of initiative, and intellectually and morally qualified for modern warfare. They had to possess "positive discipline" instead of a preference for blind obedience to orders. They had to act independently, without direct supervision, but nevertheless had to possess an inner sense of duty.

Ultimately, the essence of the message was that successful modern warfighting involved a fundamentally new relationship between society and the military. The modern soldier had to represent the best of the nation. Everyone, including the elite, or maybe rather especially the elite, needed to be able to bear arms. If the Dutch army was in any way to be effective in modern warfare, it desperately needed as its officers the educated, intelligent and responsible sons of the bourgeoisie. The army needed to be anchored in society far better. A professional army, isolated from a prosperous society, would not do. Society as a whole needed to be trained militarily, and its members physically and mentally prepared for war from a young age onwards.

This is probably the real explanation why Ram, Thomson, Asselbergs and Nix, despite all their criticism, were so fascinated by the Boer army. It was the organisation of the Boer army that appealed to the Dutch, the fact that these civilian 
soldiers were incorporated in South African society and represented its bellicose values. This was a militia of armed burghers! The Boers were a fighting nation, a real nation-in-arms. Before the very eyes of the Dutch, an immense professional army had clashed with militia. Each had its own specific forms of military action, its own kind of relationship to society, and its own merits and drawbacks. Often, the militia seemed to have been the strongest. This suggested to the Dutch observers that perhaps a volksleger (a people's army) was a good idea for the Netherlands as well. ${ }^{25}$ Could aspects of the Boer army/society - with some adjustments, such as the distribution of arms to the people (volksbewapening) and non-authoritarian forms of "positive discipline" - not be applied beneficially to contemporary modern Dutch army doctrine?

\section{Militia, Volksleger and Volksbewapening: The Debate after 1900}

Preferences and suggestions like these were never explicitly elaborated on in the official report by the Dutch observers. It is not easy to envision nowadays, but around 1900, a simple reflection on how thin a defensive line could be, or how much initiative a non-commissioned officer (NCO) or a soldier could be given in the offensive now that the effectiveness of the firearms had increased so much, were issues with almost explosive (political) implications in military circles in the Netherlands at the time. It was a highly controversial matter. Thomson, Ram and Asselbergs were well aware of it. The young military observers stuck in their official report to the technological-tactical details and criticised the Boers all the more for it. They went to great lengths to emphasise the lack of Boer discipline, their flawed military training, their ineffective logistics, and the poor standards of the vechtgeneraals (combat generals) in South Africa. The Boers were described as far too headstrong and too egalitarian to be good soldiers. Their militias could not serve as an example for Europe.

If, however, and no one could miss this point, the concept of the South African militia army could be combined with the national character of the much more disciplined and organised Nordic people like the Dutch, then perhaps the system might work. A European volksleger could perhaps fit modern warfare better than the traditional rigid and hierarchical armies. It would most certainly fit the Dutch landscape and the character, values and traditions of its people better than traditional armies. Suggestions like these can be found throughout the report.

As a result, the Dutch military observers positioned themselves with their report within a discussion that had been raging in military circles for quite some time. Roughly, two lines of thought can be distinguished in this debate. ${ }^{26}$ The 
dominant group, mainly consisting of general staff members, military brass and conservative politicians, opted for a large, traditional Prussian-style conscription army (also often called a volksleger, to complicate matters). The nucleus of this army was to remain professional. This professional core would train and command large numbers of conscripts, creating a massive (reserve) army, capable of participating in large decisive battles between (alliances of) great powers. This would guarantee Dutch neutrality, by showing force and by being capable of being victorious on a battlefield, if necessary. The minority, bearing in mind that Holland was a neutral state, emphasised the fact that the Swiss model, with its militia/volksleger and public armament, made much more sense for a small nation with a small army and little strategic depth.

It is obvious that the Dutch military observers concurred with the second line of thought, the nieuwe richting (the new direction) as it was called - a line that was endorsed by (radical) liberal officers like Graafland, Fabius and Kollewijn, and politically influential civilians like Kiersch and Dudok van Heel, and even a former Minister of War, ALW Seyffardt.

The establishment reacted accordingly. The simple fact of raising questions about different forms of military discipline, as the military observers had done, suggested to the general staff an intolerable lack of confidence in traditional centrally commanded heavily closed lines and the authority of the officer corps and general staff. In their view, the descriptions of the tactical subtleties of the modern open battlefield in South Africa were suggestive of a revolutionary new relationship between the military and society and between officers and men, and ultimately argued for freedom. The military establishment sensed subversive activities. Was this undermining of accepted regulations and far-reaching conclusions on issues such as hierarchy, discipline, forms of manoeuvre and the social role of the army, the result of the official observer mission to the Boer War? There was no denying: in South Africa, the young inexperienced military observers had found confirmation of their far too liberal ideas.

The report was classified as confidential, and no publication followed. ${ }^{27}$ At the presentation of the report, for a select audience, the Minister of War, JW Bergansius, characteristically came up with a compliment that turned out to be a verdict. He told his audience, which included the authors of the report, "The examinations in the report will most certainly be of greater value when considered from a historical perspective than as a resource for the establishment of our national defence." 28 This is how one neutralises unwelcome opinions: by ascribing a lot of historical value to it. 
Of course, the official response frustrated Ram, Asselbergs and Thomson immensely. After this attempt at marginalisation, they started to ventilate their opinions in a series of lectures and articles. This led to a very heated debate in the years to come. The two distinct camps dug in. The Militaire Gids became the forum of the reformers. ${ }^{29}$ The Militaire Spectator was the preferred medium for the establishment and the traditionalists. ${ }^{30}$ It was in particular CA Pop, lecturer at the Military Academy, member of the general staff, co-author of the influential Leerboek der tactiek I (Breda 1899), and editor in chief of the Militaire Spectator, who fulminated against the liberals and their pleas for a volksleger. His fulminations did not stop Ram and Thomson, who started to write on a new democratisch autoriteitsbegrip (democratic understanding of authority), from becoming wellknown military authors, parliamentarians, and public figures. South Africa, it is important to note, increasingly disappeared from this debate on the pros and cons of a militia army.

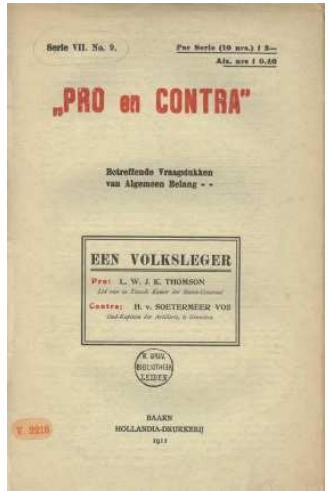

Illustration 6. A pamphlet of LWJK Thomson, on the pros and cons of a volksleger.

\section{Conclusion: Historia Magistra Vitae?}

So where does this lead us? Viewed superficially, it appears that the Dutch military observers focused on contemporary warfare in South Africa, and that they were firstly and foremostly interested in the lessons that they could learn. Apparently, their interest was not so much aroused by the supposedly historical Dutch values ascribed to the Boers by so many in Holland around 1900, as by the future-oriented military aspects of this most modern of wars they had witnessed. As a result, the observers seem to have been the odd ones out, opposing the almost unquestioned association of South Africa with the mighty Dutch past. 
But is this true? Contemporary South Africa might have gone out of focus eventually, and ultimately the observers might have been oriented towards the Dutch future. But history and Dutch "values" most certainly returned, and forcefully so. Their hope for the future, the volksleger, the militia army "South African-style", was of course loaded with supposedly Dutch values and with historical significance and meaning. Everyone must have understood that this referred to the earliest forms of the Dutch army, in its successful fight against the Spaniards around 1600. A volksleger was nothing less than the contemporary military materialisation of the "real" Dutch national character and an unjustly forgotten tradition in weaponry, mentality and ways of fighting. This way had been neglected in the nineteenth century under the influence of a far too strong focus on French and German ways of warfare. To restore Holland to its former might, a revitalisation of this very own Dutch historical military tradition was desperately needed. In effect, Thomson and his colleagues also found the foundations for a strong Dutch future in the national past, having been alerted to it by contemporary South Africa. The Boer War has famously been interpreted by JFC Fuller as the "last of the gentlemen's wars". ${ }^{11}$ It has also been interpreted by many historians as a prelude of what World War I would bring. ${ }^{32}$ For the Dutch military observers, this was not the last of the wars of the nineteenth century, nor was it the first of a new era. The war also reminded them primarily of important forgotten aspects of their own past. It was not so much that the South African present contained lessons for the future; it was by being full of remnants of the national past, that it had unexpected relevance for the Dutch military future.

It could be argued, therefore, that in all cases, South Africa has ultimately been regarded by the Dutch as some sort of past. After 1960, as before 1881, it was considered to be a past that had to be overcome. South Africa had become stuck in history. The country was on the wrong track: it chose for traditionalism and paternalism, instead of modernity, liberty and equality. It represented an outdated and oppressive past, of which one was better liberated. Around 1900, South Africa was also identified with the past. But this was now considered a good thing. The Boers represented the past that the Dutch had somehow lost and were desperately trying to retrieve as a way to compensate for their contemporary weakness. It was not an outdated past, but an inspiring one, one that had been obscured and that had come to the surface again on the Afrikaner veld. South Africa had miraculously preserved some of the values that touched on the true nature of the Dutch. No one represented this as well as the Boer generals. The Dutch military observers, although being very critical of the Boers, and never identifying with them in the way most of their compatriots did, ultimately, though along similar lines. By way of a historical 
detour, the observers also found a better national military future in South Africa, a future centred on their dreams of a militia army. ${ }^{33}$

This leads to a sobering conclusion. South Africa seems to have been a past all along. For some it was a past to dislike and to overcome; for others it was a past to glorify and to use as a source of inspiration. For all it was a past to be reduced to today's interests, pointing in the direction of the future. We like to think that the study of the past deserves an important role in society because it undermines myths and can explain to us tensions in society by means of historical narrative and analysis. We even hold that history might soften these tensions and might help to bring about reconciliation or give us the multiple identities we so desperately need. The brutal fact is that Clio legitimises most of the time. She can legitimise almost anything. David Lowenthal once suggested that the past is a foreign country. ${ }^{34}$ Fair enough. All too often, the past has been treated as a foreign country. But the opposite is also true. This seems to have happened in South Africa. The Dutch Boer enthusiasts and the Dutch military observers alike made a past out of the present of this foreign country. Worse: a Dutch past. ${ }^{35}$

\section{Endnotes}

${ }^{1}$ Maandblad Hollands Zuid-Afrika. 1881. Referred to in Maartense, K and Schutte, GJ (eds). Zicht op Zuid-Afrika: Honderd jaar geschiedenis van Zuid-Afrika, 1881-1981. Amsterdam: NZAV, 1981, 10.

${ }^{2}$ On "military memory" in general, see Murray, W \& Sinnreich, RH (eds). The past as prologue: The importance of history to the military profession. Cambridge: Cambridge University Press, 2006; Evans, M. War and memory in the twentieth century. Berg: Berg Publishers, 1997; Fussell, P. The Great War and modern memory. Oxford: Oxford University Press, 2000; Winter, J. War and remembrance in the twentieth century. Cambridge: Cambridge University Press, 1999; Winter, J. Remembering war: The Great War between memory and history in the twentieth century. Yale: Yale University Press, 2006; Mosse, GL. Fallen soldiers: Reshaping the memory of the World Wars. Oxford: Oxford University Press, 1990; Edkins, J. Trauma and the memory of politics. Cambridge: Cambridge University Press, 2003; Fleury, A. Le rôle des guerres dans la mémoire des Européens: leur effet sur la conscience d'être européen. Pietelen: Peter Lang AG, 1997; Macleod, J. Defeat and memory: Cultural histories of military defeat in the modern era. Basingstoke: Palgrave MacMillan, 2008; Schivelbusch, W. The culture of defeat: On national trauma, mourning, and recovery. New York: Picador, 
2003; Borg, A. War memorials: From antiquity to the present. Cooper: Trans-Atlantic Publications, 1990. See also: Gat, A. A history of military thought: From the enlightenment to the cold war. Oxford: Oxford University press, 2001; Gat, A. War in human civilization. Oxford: Oxford University Press, 2006; Van Creveld, M. The culture of war. New York: Presidio Press, 2008.

${ }^{3}$ This seems to be the position of Martin van Creveld in The culture of war. New York: Presidio Press, 2008. Van Creveld stresses the relationship between (military) rituals of commemoration and fighting power. He emphasises that military seem committed to military history and tradition, heroes and nationalistic rhetoric, as it bonds them as a group, and ultimately benefits combat readiness just as discipline and drill.

${ }^{4}$ On the "negative" image, regarding South Africa and the Boers, after 1960 and before 1881: Maartense, K and Schutte GJ (eds), "Een eeuw Nederlandse aandacht voor Zuid-Afrika". In Schutte, Zicht op Zuid-Afrika op. cit. pp. 338 (24-25 in particular on the "critical years" 1960-1980). Also: De Boer, S. Van Sharpeville tot Soweto: Nederlands regeringsbeleid ten aanzien van apartheid, 1960-1977. Den Haag: Sdu, 1999.

${ }^{5}$ Maartense and Schutte, op.cit. De Boer, op.cit.

${ }^{6}$ See: Schutte, GJ. Nederland en de Afrikaners: Adhesie en aversie. Franeker: Wever, 1986; Schutte, GJ. "Een eeuw Nederlandse aandacht voor ZuidAfrika”. In Maartense, K and Schutte GJ (eds), Zicht op Zuid-Afrika. Honderd jaar geschiedenis van Zuid-Afrika, 1881-1981. Amsterdam, 1981, 3-38; Schutte, GJ. "Geschiedenis Nederlands-Zuid-Afrikaanse betrekkingen: Stamverwantschap als imperialisme". Civis mundi: Maandblad voor Nederland en België. 2008. 11-19; Schutte, GJ. De roeping ten aanzien van het oude broedervolk: Nederland en Zuid-Afrika, 19601990. Amsterdam: NZAV, 1993; Schutte, GJ. "Nederland en het nieuwe Zuid-Afrika". Civis mundi: Maandblad voor Nederland en België 32/4. 1993. 143-147; Schutte, GJ. Uit het diensthuis uitgeleid. Nederlands beeld van de Grote Trek, 1838-1949. Jaarverslag van de NederlandsZuidafrikaanse Vereniging. Amsterdam, 1987, 3-24; Schutte, GJ. Kroniek van honderd jaar NZAV. Jaarverslag van de Nederlands-Zuidafrikaanse Vereniging. Amsterdam, 1980, 5-36; Schutte, GJ. De Vrije Universiteit en Zuid-Afrika, 1880-2005. Zoetermeer: Meinema, 2005; Schutte, GJ. "The Netherlands, cradle of apartheid? De Anti-revolutionairen, Abraham Kuyper en het Afrikaner nationalisme". Ethnic and Racial Studies 10/4. 1987. 392- 
414; Schutte, GJ. Nederlandse publicaties betreffende Zuid-Afrika 1800 1899. Suid-Afrikaanse Bibliotheek Grey-bibliografieë 17. Cape Town, 1989.

${ }^{7}$ See on this: Bossenbroek, M. Holland op zijn breedst: Indië en Zuid-Afrika in de Nederlandse cultuur omstreeks 1900. Amsterdam: Bert Bakker, 1996;

Bossenbroek, M. "The Netherlands and the Boer War. Their wildest dreams: The representation of South Africa in culture, imperialism and nationalism at the turn of the century". In Wilson, KM (ed.), The international impact of the Boer War. Leeds: Acumen, 2001, 123-139; De Graaff, BJH. De mythe van de stamverwantschap: Nederland en de Afrikaners, 1902-1930.

Amsterdam: Suid-Afrikaanse Instituut, 1993 (also published as Proefschrift Amsterdam, Vrije Universiteit. SAI-reeks no. 2); Kuitenbrouwer, V. A war of words: Pro-Boer propaganda and the South African War, 1899-1902. Amsterdam: Amsterdam University Press, 2010. Van Koppen, CAJ. De geuzen van de negentiende eeuw: Abraham Kuyper en Zuid-Afrika. Wormer: Inmere, 1992; Van Ledden, WP. Jan van Riebeeck tussen wal en schip: Een onderzoek naar de beeldvorming over Jan van Riebeeck in Nederland en Zuid-Afrika omstreeks 1900, 1950 en 2000. Hilversum: Verloren, 2005. For the oeuvre of GJ Schutte, also elaborating on this: note 7. Regarding the perspective of the Afrikaanders: Giliomee, H. The Afrikaners: Biography of a people. Cape Town: Tafelberg, 2003.

${ }^{8}$ Penning, L. Timotheüs. 1916/1917, 22. Louwrens Penning published an impressive number of books on South Africa (almost 20), all written before he visited the country. The famous series around field cornet Louis Wessels and his adventures amid the Second Boer War lived through 30 reprints. See for example: Penning, L. De Leeuw van Modderspruit. Zwolle: La Rivière \& Voorhoeve, 1900; Penning, L. De held van Spionkop. Zwolle: La Rivière \& Voorhoeve, 1901. Penning wrote also an autobiography and a history of the Boer War. See: Penning, L. Uit mijn leven. Zwolle: La Rivière \& Voorhoeve, 1927; Penning, L. De oorlog in Zuid-Afrika: De strijd tusschen Engeland en de verbonden Boeren-republieken Transvaal en OranjeVrijstaat in zijn verloop geschetst, 3 parts. Rotterdam: D.A.Daamen, 18991903. On Penning, see: Bescheiden betreffende L. Penning bij het SuidAfrikaanse Instituut te Amsterdam. Amsterdam: NZAV; Biografisch Woordenboek van Nederland 4. Den Haag: Instituut voor Nederlandse Geschiedenis, 1994, 382-384.

${ }^{9}$ Penning, op.cit.

${ }^{10}$ See: Lion Cachet, F. De worstelstrijd der Transvaalers. Amsterdam: J.H. Kruyt, 1881. Also: Muller, HPN. Zuid-Afrika: Reisherinneringen. Leiden: Sijthoff, 
1889; Sandberg, CGS. Twintig jaren onder Krugers Boeren in voor- en tegenspoed. Amsterdam: De Amsterdamsche keurkamer, ca. 1943; Jansen, E (ed.). Jan Hoogeveen. Lieve vrouw en kinders: Brieven van een Urker onderwijzer op zoek naar een nieuwe toekomst in Zuid-Afrika. Baarn: Bosch \& Keuning, 1983; De Louter, J. Nederland-Zuid-Afrika: gedenkboek, 18811931. Amsterdam: Nederlandsch Zuid-Afrikaansche Vereeniging, 1931; De Jong, C. Levensschetsen van Mr Dr JA Schagen van Leeuwen, 1861-1936: Een vergeten Hollander van President Kruger, en zijn zoon JJA Schagen van Leeuwen, 1896-1976, marine-officier, uitvinder en industrieel. Pretoria: De Jong, 1998; Veerman, W. "Hier leeft en geniet en strijdt men meer dan in Holland: Een brief uit Zuid-Afrika van een Culemborgse onderwijzer tijdens de Boerenoorlog”. De Drie Steden: Historisch Tijdschrift voor Tiel, Buren en Culemborg 15/3. 1994.

${ }^{11}$ See: Reitz, FW Jr \& Kiewiet de Jonge, HJ. Een eeuw van onrecht. Dordrecht: Morks \& Geuze, 1899; Kalff, S. Onder een worstelend volk. Haarlem: Tjeenk Willink, 1899; Sikken, JF. Boerenliederen: Vrij naar 't hoogduitsch van Fritz Lienhard. Amsterdam: Eduard H. Sikken, 1900; Klok, J. De Boeren-republieken in Zuid-Afrika, hun ontstaan, geschiedenis en vrijheidsoorlogen. Utrecht: De Liefde, 1901; Van Hesteren, JN. Het land van Kruger en Steijn: Transvaal en Oranje-Vrijstaat: De geschiedenis der boeren van hun vestiging aan de Kaap de Goede Hoop tot heden. Utrecht: Van der Stal, 1901; Penning, L. De oorlog in Zuid-Afrika: De strijd tusschen Engeland en de verbonden Boeren-republieken Transvaal en OranjeVrijstaat in zijn verloop geschetst. Rotterdam: D.A. Daamen, 1899-1903; Telegraaf, Oorlogskaart van Zuid-Afrika. Amsterdam: Electrische Drukkerij Amsterdam, ca. 1902; Rompel, F. Marthinus Theunis Steijn. Amsterdam: C.J. Veen, 1902; Leyds, WJ. De eerste annexatie van de Transvaal. Amsterdam: Allert de Lange, 1906; Molsbergen, ECG \& Visscher, J. ZuidAfrika's geschiedenis in beeld: Platen-atlas $=$ South African history told in pictures. Pictorial atlas. Amsterdam: Nederlandsch Zuid-Afrikaansche Vereeniging, 1913; Leyds, WJ. Het insluiten van de Boeren-republieken: Een vervolg op De eerste annexatie van de Transvaal, 2 parts. Amsterdam: Allert de Lange, 1914. See also: Schutte, GJ. De Boerenoorlog na honderd jaar: Opstellen over het veranderende beeld van de Anglo-Boerenoorlog 1899-1902. Amsterdam: Suid-Afrikaanse Instituut. SAI-pamflet-reeks no. 4, 1997; Bossenbroek, M. "Geschiedschrijving als hoger beroep: Willem Johannes Leyds, advocaat van de Boeren (1859-1940)". In Bossenbroek, M, Mout, MEHN, and Musterd, C (eds), Historici in de politiek Leiden: 
Centrum voor moderne geschiedenis, 1996, 191-211; Van der Peet, AJ. De

Koninklijke Marine en haar rol in de Tweede Anglo-Boerenoorlog 1899-

1900. No publisher, 1993; Otterspeer, W. "Boeren en academici: De Leidse Universiteit en het enthousiasme voor de Zuidafrikaanse Boeren rond de eeuwwisseling". De negentiende eeuw: Documentatieblad Werkgroep 19e eeuw 15/4. 1991. 203-221; Schutte, GJ. "Nederland en de eerste Transvaalse Vrijheidsoorlog, 1880-1881". Tijdschrift voor Geschiedenis 94. 1981. 565594; Kröll, U. Die internationale Buren-Agitation, 1899-1902: Haltung der Öffentlichkeit und Agitation zugunsten der Buren in Deutschland,

Frankreich und den Niederlanden während des Burenkrieges. No publisher, 1973.

12 The Dutch enthusiasm for the Boers can indeed also be interpreted as a sublimation of the hatred that was felt against the one country that Holland could not afford to wage a war against: Great Britain. The Netherlands were far too dependent on the British navy for the protection of Indonesia. Real (military) intervention was out of the question. Naturally this was frustrating, not to say humiliating, for the Dutch cherished the idea of a great military and maritime past that had culminated in four wars at sea against the British.

${ }^{13}$ On this, especially: Bossenbroek, M. Holland op zijn breedst: Indië en ZuidAfrika in de Nederlandse cultuur omstreeks 1900. Amsterdam: Bert Bakker, 1996.

${ }^{14}$ The location at the Otterloose Zand on the Veluwe seems to have been chosen (after advice in situ from De Wet himself) by the couple that commissioned the statue, the major patrons of art in The Netherlands between 1900 and 1940: Helene Müller (1869-1939) and Anthony G. Kröller (1862-1941). From 1909 onwards, large areas around Otterloo were bought by them. They completely redesigned the 6800 -acres estate, and made it into a combination of hunting grounds and farmlands. It is now the nucleus of National Park De Hoge Veluwe. It was dotted with impressive buildings, many of them designed by renowned architects such as HP Berlage, Heny van de Velde and AJ Kopholler. The St. Hubertus hunting lodge has become famous, just as the museum for modern art of Mrs Kröller, which still houses one of the finest art collections in The Netherlands. Mr and Mrs Köller-Müller, from German descent, were strongly anti-British. They commissioned the statue of De Wet in 1915, probably under the influence of the First World War and the Maritz Rebellion. They admired the Boers passionately, and general De Wet in particular, again especially for the underlying "spiritual values" he 
represented. See on Helene Müller, Anthony G. Kröller, their country-estate and the (other) monuments at Otterloo (such as the very curious one of OVS President Steyn as oriental philosopher): Rover, E. De eeuwigheid verzameld. Helene Kröller-Müller (1869-1939). Amsterdam: Prometheus Bert Bakker, 2010. On military monuments in general: Van Creveld, M. The culture of war. New York: Presidio Press, 2008, 229-248.

15 The many Transvaalwijken and monuments in Holland relating to the Boers could be characterised as open-air "portrait galleries" in stone, as visualisations/images of personnes de mémoire rather than lieux de mémoires. The Dutch seem to have favoured strongly the biographical, typological and "visual" remembrance. This is an interesting fact. In recent years especially the linguistic organisation of the past has been studied extensively, stimulated by the linguistic turn. It focussed on the metaphors and plot structures that dominated the (diachronic) constructions of historical narratives. It could very well be argued that the influence of visual and symbolic remembrance (especially outside professional historical scholarship) has been much stronger than is often thought. The Dutch remembrance of the Boer War seems at least to suggest that. On "narrativistic" remembrance: White, H. Metahistory. The historical imagination in nineteenth-century Europe. Baltimore: John Hopkins University, 1973; Ricoeur, P. Memory, history, forgetting. Chicago, IL: The University of Chicago Press, 2004; and many titles by FR Ankersmit. On pictural forms of memory: Buunk, P. Het imaginaire verleden. Beeldende kunst en geschiedschrijving. Den Haag: Kok Agora, 1994; Haskell, F. History and its images: Art and the interpretation of the past. Yale: Yale University Press, 1993; Lowenthal, D. The past is a foreign country.

Cambridge: Cambridge University Press, 1985; Lowenthal, D. The heritage crusade and the spoils of history. Cambridge: Cambridge University Press, 1998.

16 “Algemeene Weldadigheids-Verloting ten bate der krijgsgevangen boeren, hunne vrouwen en kinderen en verdere slachtoffers van den oorlog in Zuid-Afrika". Militaire Spectator 70. 1901. $828 \mathrm{ff}$.

${ }^{17}$ Not many publications exist on this. See: Wessels, E. They fought on foreign soil. Bloemfontein: Oorlogsmuseum, 2001; Schulten, P. "Nederlandse vrijwilligers in de Boerenoorlog". Armamentaria 33. 1998. 110-124; Van Dalsen, J. "Die Hollanderkorps tijdens de Tweede Boerenoorlog". Historiese Studies IV. 1943. 67; Ploeger, J. "Nederlandse militaire gedenktekens in Zuid-Afrika”. Mars et Historia 15. 1981; Zweers, L. De Boerenoorlog. 
Nederlandse fotografen aan het front. Den Haag: Sdu, 1999. Of great interest are also: Verloren van Themaat, H. Twee jaren in den Boerenoorlog: Met portret van Danie Theron en drie kaarten van het oorlogsterrein. Haarlem: Tjeenk Willink, 1903; Priem, GH (ed.). Een Nederlandsch Officier in Zuid-Afrika: Nagelaten papieren van luitenant Gerrit Boldingh.

Rotterdam: Van de Wetering, 1903. Hofmeyr NJ Jr. Zes maanden bij de commando's. Den Haag: Van Stockum, 1903.

${ }^{18}$ A "professional" military debate immediately started. See: Priem, GH \& Holda (pseud. of Adriana Jacoba Francisca Clant van der Mijll-Piepers). De oorlog in Zuid-Afrika: Bewerkt naar officieele telegrammen en particuliere brieven. Amsterdam: Boon, 1900. (containing: Priem, GH. De oorlog in Zuid-Afrika. Holda. De guerilla-oorlog in Zuid-Afrika; Korporaal Achilles (pseud. of Johannes Franciscus Nuyens). Aanleiding tot den Engelsch-Transvaalschen Oorlog: Feiten, op waarheid gegrond, en voor het nageslacht verzameld. Den Haag: Veenstra 1900; De La Rey, JH \& Smuts, JC. Ambtelijke verslagen van generaal JH de la Rey en generaal JC Smuts, alsook andere stukken betreffende den oorlog in Zuid-Afrika, kort geleden ontvangen door de Boerenvertegenwoordigers in Europa, en met hun toestemming openbaar gemaakt. Uitgaven door het Algemeen Nederlandsch Verbond. Amsterdam: Algemeen Nederlandsch Verbond 1902; Van Everdingen, W \& Kiewiet de Jonge, HJ. De oorlog in Zuid-Afrika: een beschrijving. (3 bd). Delft: Waltman, 1902-1915; Pabst, JC \& De Gelder, CC. De oorlog in ZuidAfrika. Delft: Waltman1904; Naudé, JF. Vechten en vluchten van Beyers en Kemp: "Bôkant" de wet. Rotterdam: Nijgh \& Van Ditmar, 1903.

${ }^{19}$ On this: Bruijn, JR \& Wels, CB (eds). Met man en macht: De militaire geschiedenis van Nederland 1550-2000. Amsterdam: Balans, 2003; Moeyes, P. De sterke arm, de zachte hand: Het Nederlandse leger en de neutraliteitspolitiek 1839-1939. Amsterdam: De Arbeiderspers, 2006;

Gooren, RHG. Politicians, soldiers and national defence: Military policy in Britain and the Netherlands 1870-1914. Utrecht: No publisher, 2002.

Klinkert, W. Het vaderland verdedigd: Plannen en opvattingen over de verdediging van Nederland 1874-1914. Den Haag: Sectie Militaire Geschiedenis, 1992; Klinkert, W. Van Waterloo tot Uruzgan: De militaire identiteit van Nederland. Amsterdam: Vossiuspers UvA, 2008.

${ }^{20}$ The best study on the Dutch military observers in South Africa during the Second Boer War, their official report, and their publications afterwards, is the unpublished master's thesis of Coen Buffing: Buffing, C. “Zuid-Afrikaanse lessen. Verblijf en bevindingen van Nederlandse militaire waarnemers op 
het Zuid-Afrikaanse slagveld en hun papieren oorlog tegen oude denkbeelden". Universiteit van Amsterdam, 2000. See also: De Vries, G \& Martens, BJ. "Waarnemers in de Boerenoorlog". Legerkoerier 4. 1996. 2831; De Jong, H. "Oog in oog met 'eenen Afrikaanschen Oorlog'.

Nederlandse militaire waarnemers in de Boerenoorlog (1899-1902)". Marineblad 2010, 22-28; De Jong, H. "On the Boer War and Dutch (military) memory: Aspects of the South African military history in Dutch perspective". Lecture delivered at the conference of The Historical Association of South Africa, Potchefstroom, Friday, July 9, 2010; De Jong, H. "The past as future? South Africa, the Boer War and Dutch (Military) memory". Lecture delivered at the conference of the Southern African Historical Society at the University of KwaZulu-Natal, Durban, Monday, June 27, 2011.

${ }^{21}$ Thomson's life and career is a biographer's dream. The officer, liberal parliamentarian, prolific writer and womaniser died as one of the first official peacekeepers in world history, during a mission, in Albania. On him: Schulten, CM. "LWJK Thomson (1869-1914)". Armamentaria 13. 1978. 72-92; Amersfoort, H. "Lodewijk Thomson, militair waarnemer". In Beliën, $\mathrm{H}$, Bossenbroek, M \& Van Setten, G (eds), In de vaart der volken: Nederlanders omstreeks 1900, Amsterdam: Bert Bakker, 1998, 99-113; Asselbergs, CJ. "Ter nagedachtenis van LWJK Thomson”. Militaire Spectator 83. 1914. $461 \mathrm{ff}$; Buffing op. cit., pp. 82-86.

${ }^{22}$ The remarks in this article on the facts and characteristics of the South African War follow: Nasson, B. The Boer War for South Africa: The Anglo-Boer War of 1899-1902. Cape Town: Tafelberg, 2010; Warwick, P (ed.). The South African War: The Anglo-Boer War 1899-1902. London: Longman, 1980; Cuthbertson, G (ed.). Writing a wider war: Rethinking gender, race and identity in the South African War 1899-1902. Athens: Ohio University Press, 2002; Baker, A. Battles and battlefields of the Anglo-Boer War 18991902. London: Military Press, 1999. See also: Giliomee, H \& Mbenga, B. New history of South Africa. Cape Town: Tafelberg, 2007, 218-223; Pakenham, T. The Boer War. London: Folio Society, 1979; Belfield, E. The Boer War. Eversley: Cooper, 1975; and the many other superb studies by authors such as Amery, Maurice and Grant, Breitenbach, Wessels, Spies, Meredith, Seegers, Prins, Krikler, Mohlamme, Morton, Rabie, etc. Published just after the deadline set for this article, and therefore not taken into account: Bossenbroek, M. De Boerenoorlog. Amsterdam: Athenaeum-Polak \& Van Gennep, 2012. 
${ }^{23}$ One could argue that the Ministry of Defence pulled the official military observers back. Another Dutch observer in British captivity (a real possibility in this chaotic war with no clear frontlines) might suggest that Holland was interfering with the war (while it was formally a neutral country). This had to be avoided. Furthermore: What could be learned from a war full of (counter)guerrilla? This kind of warfare would most certainly not occur in future conventional European warfare, according to the Dutch commanding generals. So there was also no good reason to let the observers stay in South Africa. At the same time, Asselbergs, Thomson and Ram themselves wanted also desperately to go home, due to "the end of the war" and personal exhaustion.

${ }^{24}$ On 19 September 1901 the military observers finished the first part of their report. On 7 December 1904 they presented the last chapters to the Minister of Foreign Affairs, being the official commissioner. The report can be found in the National Archives of The Netherlands: Rapport attaché's, Part I-IX, Algemeen Rijksarchief (ARA), Ass (Asselbergs), inv. nr. 26-31. See also: Dagboek Asselbergs, ARA, Collectie Asselbergs, inv. nr. 8. The rapport is also in the archives of the Dutch Ministry of Foreign Affairs:

Kabinetsarchief E.A. Ministerie van Buitenlandse Zaken 1871-1940, inv. nr. 178, box 213. An interesting fact is that the Dutch military attachés were given permission by Kruger and Steyn (presidents of the Transvaal and Oranje Vrijstaat) to collect, analyse and publish most of the cables that had been sent between them and their military commanders during the fighting. These cables are attached to the report (in copy). On this: Buffing op. cit, p. 56 , footnote 68 .

${ }^{25}$ On volksleger and militia: Bijkerk, RPF. Naar een weerbare natie? Het volksleger - ideaal van de linkse liberalen in Nederland in de jaren 1901-1911. Veenendaal: Rijksuniversiteit Utrecht, 1991; Schoenmaker, B. Burgerzin en soldatengeest: De relatie tussen volk, leger en vloot 1832-1914.

Amsterdam: Boom, 2009. Around 1900: Meijboom, MAEJ. Het Zwitsersche stelsel: Type van een volksleger. Leiden: No publisher, 1899; Kiersch,

HJPA. Een volksleger: Nederland en Zwitserland. Amsterdam: Van Holkema \& Warendorf, 1899; Van Dam van Isselt, WE. Een Nederlandsch volksleger. Schiedam: H.A.M. Roelants, 1904; De Koff, AJ. Een

Nederlandsch Volksleger: Allen weerbaar. Amersfoort: Van der Want, 1906; Benteijn, JM. Volksleger? 's-Gravenhage: Van Stockum, 1907; Thomson, LWJK \& Habets van Soetermeer Vos, HCME. Een volksleger. Baarn: Hollandia-drukkerij, 1912; Schoon, J. Volksleger of politieleger? De 
militaire bepalingen van den Volkenbond en Nederlands toekomstige

legerorganisatie. Amsterdam: Van Kampen, 1919.

${ }^{26}$ See on this debate: Teitler, G. "Een nieuwe en een oude richting: Militair denken in Nederland en Nederlands-Indië rond de eeuwwisseling". Mededelingen van de Sectie Krijgsgeschiedenis Koninklijke Landmacht I. 1978. 165-186.

27 This was in accordance with the wishes of the authorities in Pretoria. They had handed over their cables to the Dutch military observers, partly probably for propaganda reasons, but they did of course not like to see them published in full, given the sensitive nature of the material. This suited the Dutch government very well.

${ }^{28}$ On this: Buffing, F. Zuid-Afrikaanse lessen. Amsterdam: Universiteit van Amsterdam, 2000, 53.

${ }^{29}$ Anonymus. "De strijd in Zuid-Afrika". De Militaire Gids XIX. 1900. 117-119; Anonymous. "Britse aanvoerders in Zuid-Afrika". De Militaire Gids XIX. 1900. 26-31; Boogaard, FH. "Paul Kruger in Nederland". De Militaire Gids XX. 1901. 1-13; Boogaard, FH. "De aanleiding tot den Tranvaalschen Oorlog”. De Militaire Gids XIX. 1900. 1-14; Asselbergs, CJ. "Het gevecht bij Sannas - Post". De Militaire Gids XXIII. 1904. 58-73; Ram, T. "Lessen uit den Zuid-Afrikaanschen Oorlog”. De Militaire Gids XXI. 1902. 325346. Ram, T. "Belangrijke tactische werken”. De Militaire Gids XXI. 1903. 213-629.

30 “Een volksleger voor Nederland?" De Militaire Spectator LXIX. 1900. 1-14; RK. "Aanwijzing van officieren van het Nederlandse en Nederlandsch-Indisch leger als militair attaché, ter bijwoning van den oorlog in Zuid-Afrika". De Militaire Spectator LXIX. 1900. 355-361; Pop, GJCA. "Lessen uit den Zuid-Afrikaanschen Oorlog”. De Militaire Spectator LXXI. 1902. 530-534; Pop, GJCA. "Aan de lezers van den Militairen Gids”. De Militaire Spectator LXXI. 1902. 805-832; Pabst, JC \& De Gelder, CC. "De oorlog in ZuidAfrika”. De Militaire Spectator LXXIII. 1904. 163 ff.; Engelbregt, JH. "De regeling van het krijgswezen in de Zuid-Afrikaansche Republiek". Militaire Spectator 65. 1896. 268 ff.; "Het tegenwoordige Engelsche leger: Vertalingen en overdrukken". Militaire Spectator 68. 1899. III ff.; Kiersch, HJPA \& Moch, G. "Een volksleger: Nederland en Zwitserland". Militaire Spectator 69. 1900. 141 ff.; Unknown author. "Eene bijdrage voor de geschiedenis". Militaire Spectator 69. 1900. 354 ff; Dixi. "Gebruik van uitzetbare kogels in den Zuid-Afrikaanschen oorlog". Militaire Spectator 69. 1900. 629 ff.; Den Beer Portugael, AW. "De kleur der uniform, in verband met onze gevechtsterreinen". Militaire Spectator 69. 1900. 829 ff.; Van 
Munnekrede, PJ. "De Vredes-Conferentie en de Oorlog in Zuid-Afrika”. Militaire Spectator 70. 1901. 591 ff.; Unknown authors. "Krijgskundige beschouwingen over den oorlog in Zuid-Afrika: Vertalingen en overdrukken", "Over Koloniale troepen: Vertalingen en overdrukken", "Versterkte stellingen, beschouwd in het licht der gebeurtenissen van de in de jaren 1898 en 1899 gevoerde oorlogen: Vertalingen en overdrukken". Militaire Spectator 70. 1901; Eijsten, J. "Luitenant G. Boldingh”. Militaire Spectator 71. 1902. 269 ff.; Ram, JH. "Lessen uit den Zuid-Afrikaanschen Oorlog”. Militaire Spectator 71. 1902. 530 ff.; "Over het met gunstig gevolg aanwenden van mijn raderbaar bij het vervoer van zwaar gewonden over hobbelige wegen en geaccidenteerde terreinen in den oorlog in Zuid-Afrika en het in toepassing brengen van de met dit stelsel verkregen groote besparing van lichaamskracht bij't vervoer van vrachten in het algemeen". Militaire Spectator 71. 1902. 575 ff.; Pop, GJCA. "Ingezonden”. Militaire Spectator 71. 1902. 821 ff.; Unknown author."De Oorlog in Zuid-Afrika". Militaire Spectator 73. 1904. 163 ff.; R. "Lessen uit de twee jongste oorlogen". Militaire Spectator 73. 1904. 103 ff.; Unknown author. "Het Verbeterblad op het Reglement der Infanterie". Militaire Spectator 74. 1905. 171 ff.; Van Dam van den Isselt, WE. "Het spoorwezen en het gebruik der spoorwegen in den Zuid-Afrikaanschen oorlog”. Militaire Spectator 75. 1906. 221 ff.; C.T. "De wederwaardigheden der paarden gedurende den Zuid-Afrikaanschen Oorlog". Militaire Spectator 77. 1908. 301 ff. See also, in the Militaire Spectator: "Korte mededeelingen omtrent militaire zaken in verschillende landen" and "Overzicht van Buitenlandsche Tijdschriften". See also: Hoogeboom, A. Orgaan der Vereniging ter Beoefening van de Krijgswetenschap. 1901-1902. 508-522; Hesta, De Greve, Van Oordt, Kooleman Beynen, Van Aken. Orgaan der Vereniging ter Beoefening van de Krijgswetenschap. 1901-1902, 546-626; De Greve, H. Orgaan der Vereniging ter Beoefening van de Krijgswetenschap. 1901-1902; Graafland, G. Orgaan der Vereniging ter Beoefening van de Krijgswetenschap. 19011902, 595-598; Ram, JH. "Enkele opmerkingen van krijgskundigen aard naar aanleiding van den Zuid-Afrikaanschen oorlog”. Orgaan der Vereniging ter Beoefening van de Krijgswetenschap. 1901-1902, 147-227.

${ }^{31}$ Fuller, JFC. The last of the gentlemen's wars: a subaltern's journal of the war in South Africa, 1899-1902. London: Faber and Faber, 1937.

${ }^{32}$ See on this for example: Addington, LH. The patterns of war since the eighteenth century. Bloomington and Indianapolis: Indiana University Press, 1994, 102-132. 
${ }^{33}$ If we accept the famous classification regarding historical consciousness of Nietzsche's Second Unzeitgemässe Betrachtung, the Dutch way of dealing with South Africa "as a past" could perhaps best be called monumental, rather than antiquarian or critical. Nietzsche described it as looking for inspiration and motivation in monumentalised history, whereas the antiquarian admires the past to the extent that he wants to preserve it, and the critical stance implies condemning the past to the point that it is getting useful for the present, in order to give oneself a past a posteriori. The (Dutch) military seem to have escaped from the pure monumental instrumentalisation of the past. They clung much more to a combination of an $18^{\text {th }}$-century pragmatic educational approach (hence the 'exemplary' lessons to be learned from the past) and $19^{\text {th }}$-century confidence in the past "as a process", that could be understood and therefore its "developments" applied to the present and the future.

${ }^{34}$ Lowenthal, D. The past is a foreign country. Cambridge: Cambridge University Press, 1985.

${ }^{35}$ On historical consciousness in The Netherlands in general, see: Dorsman, L, Jonker, E \& Ribbens, K. Het zoet en het zuur: Geschiedenis in Nederland. Amsterdam: Wereldbibliotheek, 2000; Von der Dunk, HW. In het huis van de herinnering: Een cultuurhistorische verkenning. Amsterdam: Bert Bakker, 2007; Grever, M \& Ribbens, K. Nationale identiteit en meervoudig verleden. Amsterdam: Amsterdam University Press, 2007. 